\title{
Johannes Calvin and Holistic Mission of Church
}

\author{
Liem Kok Han ${ }^{1}$, Daud A. Pandie ${ }^{2}$, Fibry Jati Nugroho ${ }^{3}$ \\ \{liemkokhan@gmail.com¹, alfons050379@yahoo.co.id ${ }^{2}$, fibryjatinugroho@gmail.com $\left.{ }^{3}\right\}$
}

Reformed International Perth, Australia ${ }^{1}$, STT Reformed Internasional ${ }^{2}$, STT Sangkakala ${ }^{3}$

\begin{abstract}
A reformation unlocked a space for the revolution of the Mission of Church paradigm. Johannes Calvin is one who represented a novel paradigm of Mission of Church. He was the second generation in a line of pioneers and leaders of the Church Reformation Movement in 16C, nonetheless, he put a great role in the revolution of Mission of Church. The participated church that followed Calvin's theory and liturgy was spread around the world and named Calvinist Church. Nevertheless, in Mission of Church history, there were several accusations towards Johannes Calvin that accused him with no concern and acquittance about the mission. This article attempts to put forward the Mission of Johannes Calvin paradigm and its implication towards the holistic mission of the church. As an overview, this article will explain about three points. First, a context influences Calvin's mission paradigm. Second, Paradigm of Calvin's Mission, third, the association of Calvin's mission paradigm and holistic mission of the church. This article concludes that Johannes Calvin has to situate a holistic and comprehensive paradigm about the mission.
\end{abstract}

Keywords: Johannes Calvin; Holistic Mission; Church

\section{Introduction}

The concept of the Biblical Holistic Mission of Church is important for church nowadays to not merely emphasize the certain part of the mission of the church and ignore the other parts. The modern church needs to consider the concept of Johannes Calvin about the holistic mission of the church as one of conception to discover and develop the holistic mission that can be implemented in the modern church afterwards. Christian mission movement presently is constructed by two approaches that are; ecumenical and evangelical (oneness theory and gospel theory). The ecumenical approach emphasizes the social dimension, or else anthropocentric of Gospel. In other words, it means that the Salvation can give social effect and humanity in global. On the other side, the evangelical approach highlights the individual spiritual dimension of the Gospel. This means that is personal repentance and piety is human salvation [1]. Indeed, these approaches should be situated and comprehended as an entity.

Contrasting with the concept above, the mission should be recognized comprehensively through spiritual, moral, and social aspects. The presence of the church should not simply focus on the social reality that deals with numerous problems such as social injustice, criminals, contractions that victimize social dignity. On the other hand, the church has to be an organization that can evaluate powerful social effects from its church in various dimensions, that are individual aspects, small groups relationship, and countries and nations association. Therefore, 
the roleof the church should evaluate its existence in the mid of peoples' reality [2]. In contrary to the background above, Johannes Calvin's mission paradigm about church holistic mission be relevant. Calvin asserted that Christian lives between the ascent and Parousia [3]. The ascent, particularly is a sign of Christ coronation that be crucified and rose - now He rules as a King. From the modern Christ administration's perspective, this is the church that takes a look on backwards onto the cross and empty tomb and forwards, onto the fulfilment of everything.

\section{Results and Discussion}

\subsection{Contexts that Influence Calvin's Mission Paradigm}

The leaders of the Church reform movement have laid the theological, philosophical, and intellectual foundations that are solid for the success of the Protestant reform movement in Europe [1]. However, they did not intend to create new teaching and separate themselves from the Roman Catholic Church at that time. Stephen Tong states:

Reform theology is a movement to understand God's Word based on a pure conscience and a real sense of responsibility to God. The Reformers were honest people who wanted to return to be loyal to God and they also influenced the Church to return to be loyal to God. They do not teach new doctrines but explain doctrines that from eternal to eternal do not change based on the Word of God revealed in the Holy Scriptures [2].

In the development of Church history, the paradigm of mission has changed. The mission paradigm is also strongly influenced by ideological interests and power politics at a certain time. Calvin's mission paradigm also appears in a certain situation and context. Alister McGrath asserted: "Reformation emerged to coincide with the demands for social change, so that social and religious change went hand in hand" [3].

History records the emergence of the impetus referred to above, both externally and internally to the Church. There are three external drives [4]. First, the invention of the printing press, the strong current of thought by Byzantine scholars in the academies through the dissemination of their writings, the rediscovery of ancient manuscripts in Eastern monasteries as a result of the Crusades give credence to the hope that the encouragement of scholarship and education would produce more vitamins for the reformed of the Church [5]. In particular, it is worth mentioning the emergence of humanists who took great interest in improving human life through an in-depth study of classical documents. The key motto of humanism is ad fonts (return to sources), namely the Hebrew and Greek Bibles. Second, the growth of the feudal system was increasingly at the end of its life. European countries began to change towards autonomous governments, even each city acted as a small country. Third, in Europe, there is also a changing view of the world. The discoveries of a new continent that transcended the horizon of Europe, new developments in medicine, physics and mathematics, and the teaching of geocentrism, sparked a longing for an immediate renewal in church life.

Internally, the Church is also described as being in the dark ages [6]. First, corruption was a thriving culture that flourished in the Church, not only in Rome but in almost all of western Christianity. The practise of buying and selling positions in the Church has become commonplace as a result of the penchant for Church leaders to intervene in political affairs. Second, along with the relatively widespread practice of corruption, moral standards in monastic life have also declined. Bishops, as well as local Church priests, were involved in the affair. Not a few Church leaders have children out of wedlock. Desiderius Erasmus, a prominent humanist figure was also the illegitimate child of one of the priests [1]. Third, the teaching of the Church 
is increasingly deviating from the testimony of the Bible. The church bases its teachings more on tradition, namely decisions taken in councils that are generally made in the interests of power. On the other hand, there is a strong context that influences Calvin's missiology, namely: the ecclesiology of papalism in the Roman Catholic Church and the Anabaptist movement as a radical movement that is anti-Catholic and anti-establishment, propagating different views and opposing existing views [2].

In addition to these two contexts, the background of studies from various disciplines studied and wide association with many people more or less influenced the ecclesiology he built.The ecclesiology of papalism in the traditional Church in this paper will be seen from the understanding of the Church in the Middle Ages. In the Middle Ages, the view developed that the visible Church led by the Pope was the kingdom of God on earth and the Holy Roman Empire was its embodiment. This view is not based on theological understanding but is based on papal supremacy. The existence of papal supremacy gives rise to an understanding that the Pope is seen as the head, foundation, root, and source of all kinds of power and authority in the Church. This understanding had the effect of strengthening the authority of the Pope in the Church. The church is understood as an institution led by church officials or clergy distributing salvation to the laity [3]. The Van den End describes the Church at that time as centred on institutions and the sacraments.[4] Ideas about God, understanding of salvation and worship that is different from what was said by the Church hierarchy through councils which have been coopted by the authorities are considered heretical [5].

The church is understood as an institution led by church officials or clergy distributing salvation to the laity [6]. Church officials and the laity were elements of the structure of the Church at that time. The so-called Church officials are the clergy consisting of bishops and the pope as head. These officials do not have the same authority. The pope has greater authority while the authority of the bishops is received from the pope. The papacy is central to the hierarchically strict structure of ecclesiastical officials. The church is described as a congregation with leadership [7]. Calvin rejects the papal system because in the papal system there is a single and authoritarian ruler.

Another context of papal ecclesiology is the Anabaptist movement as a radical movement that is anti-Catholic and anti-establishment, propagating different views and opposing existing views. Calvin refuted Anabaptist teachings on several points about the Church, the Church's attitude toward the state, baptism, discipline, oaths, and the state of the soul after death. The objections related to Anabaptist teachings are contained in his book Institutio. Maintaining the purity of the Church was an important aspect of Anabaptist ecclesiology.

The church must be maintained without blemish and blemish. Although the Church is not perfect, it must try to be close to the purity of life. This effort is carried out by imposing Church discipline. The morals and ethical behaviour of Church members receive serious attention. If any member is found to have violated discipline and behaved deviating from the biblical standard of living, he or she will be punished with ex-communication. Calvin refuted Anabaptist teachings by explaining as follows:

True, Indeed, is Paul's statement:" Christ...gave himself up for the church that he might sanctify her; he cleansed her by the washing of water in a glorious bride, without spot or wrinkle,"etc.(Eph. 5:25-27 p). Yet it also is no less true that the Lord is daily at work in smoothing out wrinkles and cleansing spots. From this, it follows that the church's holiness is not yet complete. The church is holy, then, in the sense that it is daily advancing and is not yet perfect. It makes progress from day to day but has not yet reached its goal of holiness, as will be explained more fully elsewere [1]. 
Christ as head of the Church does not organize directly but entrusts it to Church officials. In this regard, Calvin gave a central place to the ecclesiastical office. So central that it hardly seems to have anything to do with the general priesthood of the people. Indeed, he did not place the ecclesiastical office above the congregation, as did the Roman Catholic Church, but giving the ecclesiastical office a central place made a difference between them and the rest of the congregation.

\subsection{Calvin's Holistic Mission Theology Foundations}

Calvin's theology, as summarized in the Institute, was shaped by his belief in God's creation, salvation and God's glory as of the goal. Speaking of the glory of God, Calvin stated that God created man for His glory. "Adam was taken from earth and clay... nothing is more absurd to those who... dwell in the house of clay... than the source of their superiority. But...God...was humble enough to give life to a clay vessel, but also wanted it to be a dwelling place for an immortal spirit" [2]. Calvin further explained, "Why did God create us in His image and likeness if not so that His light might shine within us!" [3].

Other points in Calvin's theology, such as predestination or redemption, are built on a belief in the limitations and glory of God. it is not wrong if many praise Calvin's theology as a theology of praise and glory of God [4]. Calvin's understanding is based on the Bible because he strongly emphasizes that reformation is formulating a theology based on the Bible. Calvin because of the assessment of the Bible as the only true source of Church teaching, Calvin rejects the Roman Catholic Church's appreciation of tradition as a source of belief and teaching that is equivalent to the Bible. According to Calvin:

For if the Christian church was founded from the beginning on the writings of the prophets and the preaching of the apostles, wherever this doctrine is found, its acceptance - without which the church itself could never have existed - must have preceded the church [5].

Calvin very important pedagogical aspects of the Bible. According to Calvin, what is to be sought in the Bible is knowledge of God and that knowledge can only be found in Jesus Christ. The Bible is not enough just to be read and understood literally but must be placed within it, keeping in mind that the study must be centred on Christ who is the centre of the Bible [5]. Speaking of the glory of God, Calvin asserts that God created the world and man for His glory. God not only tells and announces that we should worship God, but also that He should be worshipped, and if He not only teaches His elect to look to God but at the same time reveals Himself so that He is the one they look up to. Therefore, everything that happens in this world and everything that humans do is aimed at glorifying Him [1].

Calvin's emphasis on the glory of God was followed by an emphasis on sanctification. Humans who have been forgiven and justified by faith must try as much as possible to maintain and strive for the holiness of their lives, even though holiness is never perfect and is not intended to obtain forgiveness and justification from God. On the contrary, humans try to maintain holiness because they have been forgiven and justified first. Justification by faith cannot but be based on forgiveness.

Calvin defines salvation as the eternal decree of God, by which He determines for Himself what He wills will happen to each person. Thus the redemption of Christ is limited to those who have been chosen, salvation is impossible for all men, it is only provided for those who have been predestined to be saved. Calvin's understanding of people who have been saved by God's grace in Jesus Christ, who have been justified even though they are still sinners, all of which are welcomed and accepted by humans through faith. In line with the understanding of the Bible 
which is centred on the gospel of Jesus Christ, it is emphasized that the Church is a place that can be found anywhere as long as there the Word of God is preached purely and heard, and the sacraments are administered according to the rules of Christ. further emphasized that God calls and provides those who are tasked with preaching the Word and administering the sacraments and that pastors guide and build up members of the Church. That is why the Church needs ecclesiastical officers. The theoretical foundations for the Church's system of government have been laid out in the Institutio, while the elaboration is contained in his small paper Ordonnances Ecclesiastiques (Church regulations) written in 1541. These regulations were written for the needs of the Protestant congregation in Geneva, where Church officials and the city government have a very close relationship.

The church that Calvin served as the Geneva congregation where the Church was supported and financed by the state. By 1560 Geneva had become the model for the Calvinist Church throughout Europe. It became a model for a devout city that had been reformed ${ }^{3}$. Because of its wealth of archival material, Geneva is also a place to study early modern society and culture, where the Reformation and Calvinism were intertwined4. The state supports and protects the worship of God from an outward point of view, maintains sound teachings on religion, defends the position of the Church, regulates the life of the Church based on community association, fosters morality in accordance with justice as stipulated by state law, reconciles and fosters peace and general peace.

The church is understood by Calvin through two sides, namely the visible Church and the invisible Church. The invisible church is the Church in the truest sense, the body of Christ consisting of people, both living and dead, who are truly called by God to be His children. In other words, the invisible Church is a community of saints who are chosen and whose electability is known only to God5. While the visible Church is a community of Christians. Calvin's Understanding of the Church as visible and invisible was influenced by Augustine. The visible church and the invisible church must be distinguished but cannot be separated. The visible church must try to reflect as best we can on what is believed about the Church as the invisible body of Christ [1].

The understanding of the visible and invisible Church is also defined by Barth. According to Barth, the invisible Church is referring to the hidden source of God the Holy Spirit so that the Church cannot be compared to society. Hence, its nature and essence cannot be found on the human level but in the spiritual reality of encountering God and this reality can only be seen through faith. That is why the Church is different from other institutions. Meanwhile, the visible Church according to Barth is a form of the invisible Church. The visible church is a representation of all those who by the miraculous work of the Holy Spirit live in peace with God $^{2}$. Although Calvin and Barth's understanding of the invisible and visible Church is different, they both emphasize that the invisible Church comes first and then the visible Church. Both understand that the visible and invisible Church are two inseparable things.

Calvin also used biblical elements in determining the true Church. The church will be called the Church if the Word of God (the Bible) is purely taught and the sacraments are administered according to the decree of Christ. The Bible is the standard for judging the preaching of the Word and the ministry of the sacraments. So, as long as the Word of God is preached purely and the sacraments are administered the name "Church" will remain. Thus, for Calvin, the preaching of the Word of God (the Bible) is the main thing and priority in the life of the Church. According to Calvin, the Church is one as the Apostles' Creed says "the universal". The unity of the Church-visible and Church-invisible lies in Christ as the Head of the Church connecting the members of the Church in one body. When Calvin spoke of the visible Church he described the Church as "mother", meaning that the name "mother" was of great use. There will be no 
access to life unless we are conceived in its womb, born by it, breastfed by it, and finally protected and guided by it. Apart from him, we cannot expect forgiveness of sins and happiness so that anyone whose way of life deviates from the rules of the Church will surely meet destruction [3]. The whole of Calvin's ecclesiology is an attempt to make the Church an institution for the formation of the person and society because man is in an imperfect condition. Institutional discipline is important to organize life and the educational process. Calvin argued that order was needed in ecclesiastical institutions and officials.

\subsection{Calvin's Mission Paradigm}

Calvin in the context of reformation provides a paradigm shift about the mission. He views the mission, among other things, to unite God's people who have been scattered through persecution, as a theological renewal of the Church, as a reunification of Churches that are separated from one another; as an effort to support the Churches who are oppressed and who are becoming poor, and as an effort towards the liberation of Churches that are facing challenges from the Roman Catholic Church4. Calvin regarded the Pope, bishops, orders and congregations, and secular authorities as unfit agents for the mission. Only the Church can be a legitimate missionary.

A basic feature of Calvinism is the doctrine of Predestination. This doctrine has often been understood in a rigid sense: when God has set people on salvation, then they must leave it to Him to save whom He wants to save, as He pleases. And it is this belief that can paralyze the desire to undertake a mission. Whereas in Calvin's concept, the emphasis on predestination leads to active involvement in mission; God's elect cannot remain silent1. Here Calvin wants to emphasize the glory of God (Gloria Dei). For Calvin, glory was very important. All for the glory of God. So God's chosen people certainly must not remain silent to win every area of life for the glory of God [2].

The Word of God is the only norm underlying the concept of predestination. David J. Bosch quotes Calvin, explaining:

If this thinking applies to us, it is that God's Word is the only way that can lead us in exploring all that is allowed to be believed concerning Him and is the only light that illuminates our vision of all that we should see about Him. Him, this will guard and limit us from all carelessness. Because we know that the moment we cross the boundaries of the Word, our steps get off track and into darkness and that there we must repeatedly stray, slip, and stumble. Therefore, let this matter first before our eyes: to seek any other knowledge of predestination than what the Word of God reveals is no less insane than if one were to purposely walk in the deserted wilderness or see in the dark [3].

In terms of the Calvinistic paradigm, another dimension added is theocracy. Where the Calvinist mission is carried out, it intends to establish in the "wilderness" a socio-political system, in which God himself will be the real ruler. Theocratic ideas are closely related to how Calvin understood the relationship between mission and eschatology. He has postulated three stages in the Church age. The first period was the apostolic period when the gospel was offered to all the inhabited world. Then comes the second period in which the Antichrist reigns and in which Calvin himself lives; therefore he wrote a theology for the Church under the cross. The last period was the great expansion of the Church [4].

The Kingdom of God or the Kingdom of Heaven (Matthew's Gospel version) is the starting point of Jesus' leadership. Mark's Gospel briefly describes the essence of Jesus' preaching that began immediately after winning the temptation in the wilderness: "The time is fulfilled; The kingdom of God is at hand..." (Mark 1:15; also Matthew 4:17). It should be noted that the 
'proclamation of the kingdom of God' was carried out by Jesus not in Jerusalem which was the centre of power, but in Galilee which was the environment of the small people. The concept of the Kingdom of God is inherited from the Old Testament tradition, the core of which is the recognition that the real king is God himself. Only God has the right to absolute obedience, whereas obedience to all human kings is relative: as long as the king obeys God's will and exercises his power with high regard for justice, loyalty, and responsibility. Thus, 'Kingdom of God' theology generalizes and relativizes human powers.

The concept of mission according to Yohannes Calvin cannot be separated from three important things related to the mission in Calvin's thought, namely: First, Calvin strongly emphasizes the importance of preaching the gospel, as God's way of inviting all people to salvation, because the application of salvation by the Holy Spirit is preceded by the call of the gospel; second, Calvin was concerned with "gentiles", for they too Calvin hoped to enjoy the doctrine of salvation; third, For Calvin, all people are allowed to be called through the preaching of the gospel. Thus, Calvin's mission is not exclusive, but inclusive, that is, to all people. Likewise, Calvin asserts that the Lord Jesus was not only sent to the Gentiles. This he confirmed by quoting the text of Isaiah 2:4, that: "He will be Judge among the nations [1].

In Geneva, Calvin also founded schools. In Geneva, an Academy was founded which had two parts, namely the gymnasium and the theology. Theodorus Beza was appointed director of the Academy. It was at this Academy that young Calvinists who would later become leaders of the famous Calvinist Church were prepared, such as John Knox, Caspar Olevianus, author of the famous Heidelberg Catechism.

Calvin himself was a mission director for the Church of Geneva. In other words, Calvin is not only qualified as a theologian, churchman (doctor ecclesiae), but as a regulator of missionaries, therefore, the title director of missionaries for Calvin is certainly not an exaggeration. BR Easter even writes more appropriate things for Calvin, that: All aspects of Calvin's thinking are important to missionary endeavours. He is missionary-minded when he sees people in bad condition, the grace of God in Christ, and the duty of the Church to preach the gospel to all people; also because his whole life is concerned with believers who are abroad, his concern is to spread the understanding of the biblical faith in Europe, this shows the spirit of his mission [2].

The significance of Calvin's exemplary Church mission is his emphasis on biblical Christian teachings to the congregation through sermons as well as teachings. The church is responsible for educating the congregation so that in all aspects of human life, whether in the political, economic, social, cultural, educational, and other fields, the glory of God radiates because Christ is enthroned in all aspects of human life. One of Calvin's great works that became the treasure of the Church was the book Institutio (Teaching the Christian Religion) which became a guide for teaching the Christian faith. Calvin's mission is to return the Church to the truth of the time and in its context, so our mission in these last days is also to maintain the biblical teaching of the Church and to return the Church which has started to leave the biblical truth to the basis of biblical teaching, namely the apostles.

Calvin did a lot of work tirelessly. Since 1558 his illness began to be severe. Before his death, he left many messages to his congregation and to Theodorus Beza, who would take his place in the Geneva congregation. He called the City Council and the pastors to listen to his counsels. On May 27, 1564, Calvin died peacefully. He left leaving the hard work to Theodorus Beza. His name is remembered throughout history throughout the world with the imprint of the Calvinist Church. The mission is mission Dei, which seeks to put within itself missions ecclesiae, the Church's missionary program. It is not the Church that seeks the mission; rather it was mission Dei that created the Church. The mission of the Church must be constantly renewed 
and rethought. The concerns of the Church are conversion, Church growth, God's government, economy, society and politics. Missio Dei purifies the Church for a holistic mission.

\subsection{The relevance of the Calvin Church's Mission Paradigm for the Holistic Mission of the Church Today}

Based on the above study, it is clear that John Calvin in his context has laid down a holistic and comprehensive mission paradigm on the mission, and Calvin's concept of the Church's Holistic Mission is relevant for the holistic mission of the Church today. Calvin's mission was to restore the Church to truth in its time and its context. Calvin is indeed recognized as a theologian who is rich in doctrinal ideas, but it cannot be denied that in all his theological writings Calvin has indirectly provided the basics of thinking about mission. Calvin has emphasized the sovereignty of God's Word in the Church. He also emphasized the sovereignty of God's grace in salvation. Calvin's motto, sola gratia, speaks of the absolute mercy of God, and this is the proclamation of the Church; it gives to the Church a complete gospel and purifies evangelical motives. Then, he further taught about God's sovereignty overall life. Christians should glorify God in every existence. He must live fully to glorify God. This means obedience is ongoing throughout life.

The significance of Calvin's exemplary Church mission is his emphasis on biblical Christian teachings to the congregation through sermons as well as teachings. The church is responsible for educating the congregation so that in all aspects of human life, whether in the political, economic, social, cultural, educational, and other fields, the glory of God radiates because God is enthroned in all aspects of human life. In the context of Indonesia, the struggle for the holistic mission of the Church includes pluralism religion and culture; high levels of poverty; suffering from conflicts and riots, injustice in various fields of life and ethnic and gender discrimination, and environmental damage. The church is called to enter and together with other elements of the nation seek change and renewal in these various life crises.

\section{References}

[1] Richard. D Siwu, “Misi Dalam Pandangan Ekumenikal dan Evangelikal Asia,” Jakarta: BPK Gunung Mulia, 1999, hlm 28.

[2] Tissa Balasurya, Teologi Ziarah, Jakarta: BPK: Gunung Mulia, 1997, 187

[3] Alfred C. Krass, "On Dykes, the Dutch and the Holy Spirit," Milligan Missiogram, vol 4. No. 4, 1978, pp. 11

[4] Ahmad Suhelmi, "Pemikiran Politik Barat," Jakarta: PT Gramedia Pustaka Utama, 2007, pp. 156.

[5] Stepen Tong, Reformasi dan Teologi Reformed, Jakarta: LRII, 1991. pp. 79.

[6] Alister McGrath, "History of Reformed Thought," Jakarta: BPK Gunung Mulia, 1999, pp. 19

[7] Bnd. Ebenhaezer L Nubantimo, "Gereja Bertindak Terhadap Sang Lain," dalam Yusak Solei man, "Dari Wittenberg kita semua Terpanggil Membarui Dunia," 1517-2017, Jakarta: BPK Gunung Mulia, 2017, pp. 153.

[8] Justo L. González, "The Story of Christianity," Vol. 1: The Early Church to the Dawn of the Reformation, New York, Harper Collins Publisher, 2010, p 10.

[9] Christian de Jonge, Church Looking for Answers. Jakarta: BPK Gunung Mulia, 2000, pp. 2. 
[10] Tony Lane, Runtut Pijar: Sejarah Pemikiran Kristiani [The Incandescent: The History of Christian Thought], Jakarta: BPK G unung Mulia, 2008, p. 27.

[11] Agustinus Batlajery, Konteks yang mempengaruhi Eklesiologi Calvin. Waskita. (April 2014), p. 119-120

[12] Christian de Jonge, What and How Church is. Jakarta: BPK Gunung Mulia. 1998. p. 9.

[13] Th. Van den End, Treasure in a Vessel, Jakarta: BPK Gunung Mulia, 1995, hlm 141.

[14] B.S. Mardiatmadja, Ecclesiology Meaning and History, Yogyakarta: Kanisius, 1986, pp. 11.

[15] Calvin, Institutes of The Christian Religion Vol 2, ed. John T.McNeil, London:Westminster John Knox Press.

[16] Herman J. Selderhuis, Buku Pegangan Calvin [Calvin's Handbook], Surabaya: Momentum. 2017. pp. 298-299.

[17] Jan S. Aritonang, Various Sects in and Around the Church, Jakarta: BPK Gunung Mulia, 2008, pp. 64

[18] Th van den End, Enam Belas Dokumen Dasar Calvinisme, Jakarta: BPK Gunung Mulia, 2004.

[19] Ebenhaizer I, Nuban Timo, “The Eschatological Dimension on Karl Barth's Thinking and Speaking about the Future". A Dessertation, Theologische Universiteit Van De Gereformerde Kerken in Nederland te Kampen, 2001, pp. 281-282

[20] David J Bosch, "Transformasi Misi Kristen: Sejarah Teologi Misi Yang Berubah dan Mengubah [Transforming Mission: Paradigm Shifts in Theology of Mission]," Jakarta: BPK Gunung Mulia, 2009.

[21] Edwin H. Palmer, Lima Pokok Calvinisme, Surabaya: Momentum, 2011, pp. 186.

[22] William R. Huthchison, "A Moral Equivalent for Imperealism American and the Promotion of Christian Civilization". Dalam Christensen dan Huthchison, 1982, pp. 167-178.

[23] John Calvin, Commentaries on the Book of the Prophet Isaiah, Grand Rapids: Baker Book House, 1981, pp. 99

[24] B. R. Easter, "Missions in the Reformed Tradition," Puritan Paper, Volume Two, 19601962, edited by J. I. Packer, New Jersey: P\&R Publishing, 2001, pp. 144. 